\title{
ANTECEDENTS AND IMPLICATIONS OF INNOVATION CAPABILITY: EMPIRICAL STUDY OF BAKPIA MSMES IN YOGYAKARTA
}

\author{
Baroroh Dwi Nurhayati ${ }^{1 *}$ Titik Kusmantini ${ }^{1 *}$, and Tri Wahyuningsih ${ }^{1}$ \\ Department of Management, Faculty of Economics and Business, Universitas Pembangunan \\ Nasional "Veteran" Yogyakarta, Sleman, Yogyakarta, 55283, Indonesia
}

\begin{tabular}{|c|c|}
\hline ABSTRACT & ARTICLE INFO \\
\hline 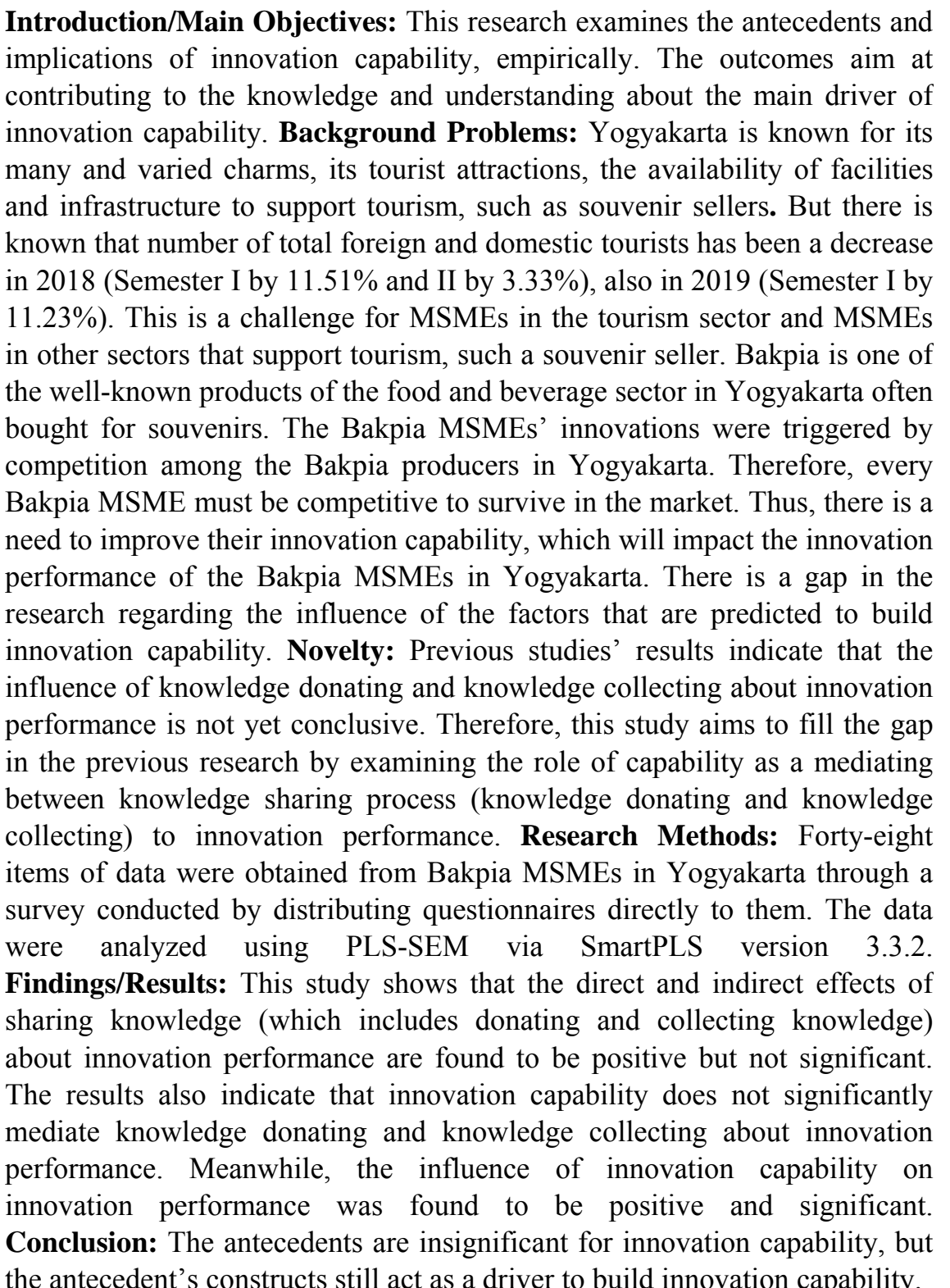 & $\begin{array}{l}\text { Article information: } \\
\text { Received } 1 \text { November } \\
\text { 2020. Received in revised } \\
\text { form } 25 \text { March } 2021 . \\
\text { Accepted April } 26 \text { April } \\
2021 . \\
\text { Keywords: } \\
\text { knowledge sharing } \\
\text { process, knowledge } \\
\text { donating, knowledge } \\
\text { collecting, innovation } \\
\text { capability, innovation } \\
\text { performance } \\
\text { JEL Code: } \\
\text { - }\end{array}$ \\
\hline
\end{tabular}

\footnotetext{
* Corresponding Author at ${ }^{1}$ Department of Management, Faculty of Economics and Business, Universitas Pembangunan Nasional "Veteran" Yogyakarta, Sleman, Yogyakarta, 55283, Indonesia

E-mail address: rorokartodikromo@gmail.com (author\#1), titik.kusmantini@upnyk.ac.id (author\#2), triwahyuoke@gmail.com (author\#3)
} 


\section{INTRODUCTION}

Innovation is one way to survive and compete in a business environment that constantly evolves. According to Dereli, (2015) companies are required to be able to maintain their competitiveness, improve their performance and economic growth, and contribute to their economic development through innovation. Innovation refers to the creation and application of new knowledge and to the development of new technologies, new processes, new products, and new services, therefore knowledge has become a key resource for innovation and development (Chuluun et al., 2017; Wang et al., 2020). Hence, it is necessary to recognize the elements that form innovation capability and innovation performance (Yeşil et al., 2013). According to Birchall et al. (2011) the measurement of innovation performance has attracted a lot of attention from researchers and practitioners. Innovation performance, as defined by Zizlavsky (2016) is "the ability to convert innovation inputs into outputs." Innovation requires an enterprise to exchange the inputs, such as materials, information and energy with the external environment, especially knowledge (Wang et al., 2020). The key to continuous innovation is knowledge, so innovation and knowledge are defined as being closely related. Yeşil et al. (2013) also argued that the knowledge created, transferred, and shared within a firm is also a source of innovation. A previous study by Ritala et al. (2015) showed that external knowledge sharing positively affects innovation performance. However, Jantunen et al. (2008) showed that knowledge sharing horizontally and vertically did not have a significant effect on innovation performance. The research results of Yeşil et al. (2013) also found that the knowledge sharing process, which includes knowledge donating and knowledge collecting, did not have a significant effect on innovation performance. Previous research results have indicated that the influence of knowledge donating and knowledge collecting on innovation performance is not conclusive. The accumulation of donated and collected knowledge is able to create an innovation capability, which can provide the innovation performance desired by a company. Therefore, researchers in this case take the opportunity to examine innovation capability as a mediator in this study. Yeşil et al. (2013) also suggested that perhaps the knowledge sharing process affects innovation performance through innovation capability.

Innovative capability is one of the key organizational tools for surviving external unpredictability (Calantone et al., 2002; Ganguly et al., 2019). Innovation capability provides a firm with a sustainable competitive advantage to implement its overall strategy (Ganguly et al., 2019; Rajapathirana \& Hui, 2018). The accumulation of knowledge donating and knowledge collecting will improve innovation performance when there is an increase in the technical capabilities in micro, small and medium enterprises (MSMEs). MSMEs can achieve effective innovation performance through continuous improvement of their innovation performance, which MSMEs emphasize. According to Lawson \& Samson (2001), innovation capability is the ability to continuously transform knowledge and ideas into new products, processes, and systems for the benefit of a company and its stakeholders. Some researchers are concerned and interested in examining the antecedents of innovation capability (Ganguly et al., 2019).

The research results from Lin (2007), showed that a company's innovation capability was positive and significantly related to its employees' willingness to donate and collect knowledge. However, the research results from 
Liao et al. (2007) stated that knowledge sharing, which includes knowledge donating and knowledge collecting, significantly affects innovation capability through absorption capacity, and a fit or suitable research model is a fully mediated structure. It means that innovation capability is not directly affected by knowledge sharing, including knowledge donating and knowledge collecting. Meanwhile, Yeşil et al. (2013) argued that innovation capability was influenced positively and significantly by knowledge donating. However, knowledge collecting insignificantly affects innovation capability. Furthermore, Lawson \& Samson (2001) stated that the stronger a company's innovation capability was, the more effective its innovation performance is. Previous studies show that innovation capability affects innovation performance (Prajogo \& Ahmed, 2006; Sözbilir, 2018; Utoyo et al., 2020; Yeşil et al., 2013).

Thus, there is an exchange of ideas, information, experiences, and skills among MSME individuals (the owners, managers, employees, competitors) in the knowledge sharing process. This is also seen in the Bakpia MSMEs in Yogyakarta, who carry out the knowledge sharing process through their association's meetings as well as interactions and communications that exist between the owners or managers and employees, and also the competitors, in order to innovate. The success of knowledge sharing encourages knowledge creation, increasing the capability for continuous innovation (Sulistiyani \& Harwiki, 2016).

This research focuses on the MSME sector because Yogyakarta is actively involved in the region's and nation's economic development. There are $14 \%$ of all the businesses in Yogyakarta are classified as MSMEs (Koperasi
\& DIY, 2017). The city of Yogyakarta is known for its many and varied charms, its tourist attractions, the availability of facilities and infrastructure to support tourism, such as accommodation, restaurants, telecommunications, entertainment venues, and souvenir sellers. Therefore, Yogyakarta has received the title of the "Leading Tourist Destination Area." Data from the Yogyakarta Special Region Tourism Office shows that the number of tourist visits, by both foreign and domestic tourists, is as follows in Figure 1.

In the chart above, it can be seen that the number of foreign and domestic tourists entering Yogyakarta, based on the data by semester from 2017 to 2019 has fallen. Domestic tourists increased in Semester II 2017, but decreased in Semester I 2018 to Semester II 2019. Foreign tourist numbers were unstable, increasing in Semester II 2017, Semester II 2018, and Semester II 2019, but decreasing in Semester I 2018 and Semester I 2019. It can be concluded from total of foreign and domestic tourists that there has been a decrease in the number of foreign and domestic tourists in Semester I 2018 to Semester I 2019 by $11.51 \%, 3.33 \%$, and $11.23 \%$. In addition, Yogyakarta is one of the cities affected by the COVID-19 pandemic, which has caused a slow-down or decrease in all the business sectors, but especially tourism and tourism support businesses, such as the food and beverage sector. This is a challenge for MSMEs in the tourism sector and MSMEs in other sectors that support tourism, such a MSMEs in food and beverage sector in Yogyakarta. Primasari \& Siswojo (2016) stated that travel, no matter what the purpose of tourists coming to Indonesia to enjoy nature, culture, attractions, or entertainment, there will be definitely a need to eat. 
The Number of Tourist Visits in Yogyakarta City Tourist Attractions at 2017-2019
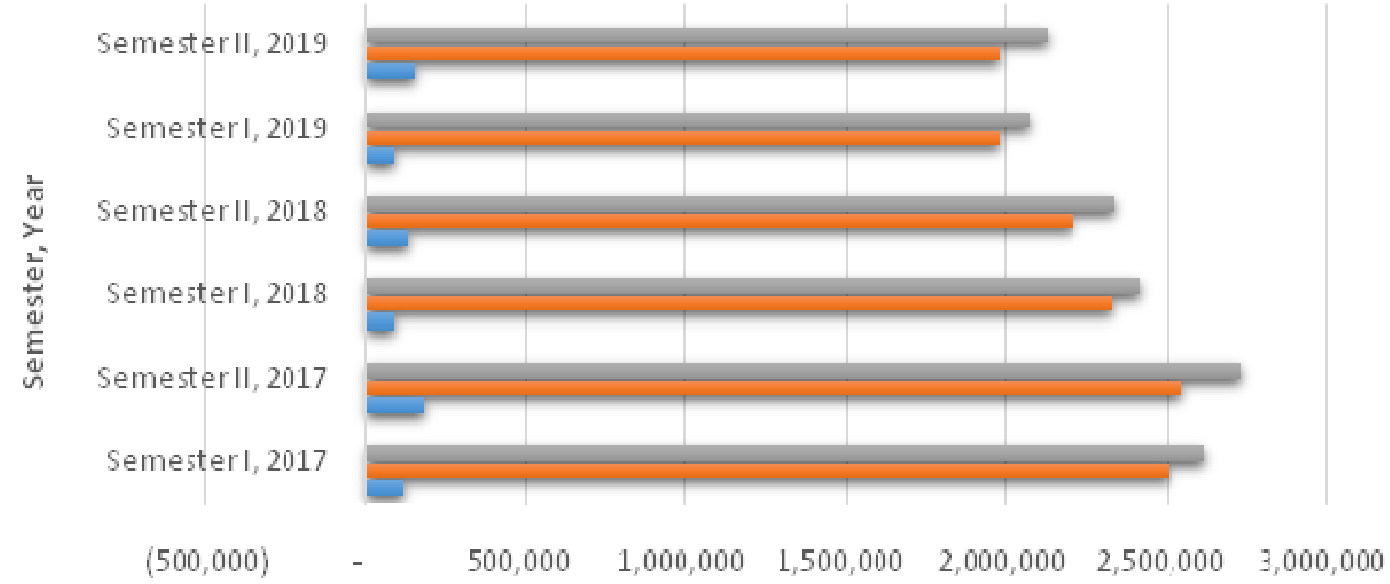

\begin{tabular}{|c|c|c|c|c|c|c|}
\hline & $\begin{array}{c}\text { Semester } \\
1,2017\end{array}$ & $\begin{array}{c}\text { Semester } \\
\text { II }_{2} 2017\end{array}$ & $\begin{array}{c}\text { Sementer } \\
1,2018\end{array}$ & $\begin{array}{c}\text { nepreftot } \\
\text { II, } 2018\end{array}$ & $\begin{array}{c}\text { Semester } \\
I_{1}, 2019\end{array}$ & $\begin{array}{c}\text { Semester } \\
\text { II }, 2019\end{array}$ \\
\hline Percentage of TOTAL & & $4.35 \%$ & $-11.51 \%$ & $-3.33 \%$ & $-11.23 \%$ & $2.62 \%$ \\
\hline = TOTAL & $2,616,857$ & $2,730,769$ & $2,416,375$ & $2,335,976$ & $2,073,539$ & $2,127,831$ \\
\hline EDOMESTIC & $2,500,670$ & $2,543,938$ & $2,327,438$ & $2,205,581$ & $1,982,417$ & $1,976,911$ \\
\hline EOREIGN & 116,187 & 181,831 & 88,937 & 130,395 & 91,122 & 150,970 \\
\hline
\end{tabular}

Source: (Dinas Pariwisata Daerah Istimewah Yogyakarta, 2017-2018; processed by authors, 2019)

Figure 1. The Number of Tourist Visits to Yogyakarta's Tourist Attractions from 2017 to 2019

Data from Yogyakarta's Department of Industry and Trade about the creative industries in Yogyakarta shows that the food and beverage sector is in the first place with $40 \%$ of the total creative industry. That means the creative industry in Yogyakarta is dominated by MSMEs operating in the culinary field. Then, followed by crafts by $19 \%$ and other creative industry sectors, such a product design, film and animation, crafts, fashion, and games and applications (Sugondo, 2019). In more detail, the number of creative industries in the food and beverage sector in Yogyakarta is 1,202 consisting of more than 50 types of food and beverage businesses. The number of Bakpia businesses in Yogyakarta is known to be in second place, after the various snack businesses; Bakpia is one of the well-known industries in the culinary sector in Yogyakarta. Bakpia is a food made from a mixture of mung beans and sugar wrapped in flour and then baked. The flavor of Bakpia is not only green beans. In order to innovate, Bakpia MSMEs try to make continuous improvements to their product. Bakpia is not only made in the conventional way, which is baked, but it is also made using new concepts and methods, which is steamed. The way it is made affects the texture and the filling of the Bakpia and now the flavors of Bakpia are also becoming increasingly varied. Usually, Bakpia MSMEs only make Bakpia with a choice of fillings: mung beans, chocolate, cheese, or "kumbu hitam". However, now, Bakpia is made with contemporary flavors following market trends, namely green tea or matcha, taro, red velvet, strawberry, and durian. 


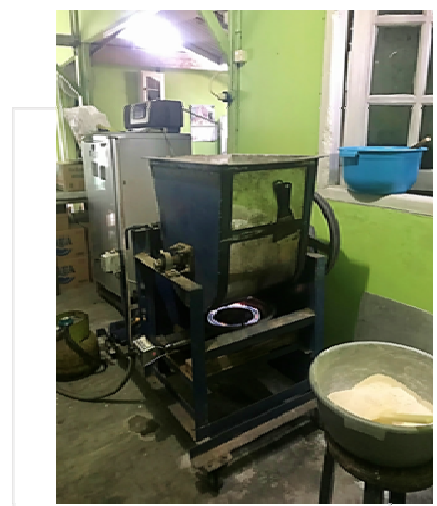

a)

\section{Note:}

a) The madern machine used to produce Bakpia. The machine is driven using 2000 watts of electric power and gas.

b) The dough rolling stage uses a machine for $10-15 \mathrm{~kg}$ production capacity.

c) The Bakpia drying process place.

Source: Research Documentation, 2019

Figure 2. The Process of Making Bakpia Using Technology

Bakpia is called "identical food" from Yogyakarta. Foreign and domestic tourists who visit Yogyakarta often buy Bakpia as souvenirs. They choose Bakpia as a souvenir because of the natural ingredients in the right blend makes Bakpia a typical souvenir of Yogyakarta. The advantage of Bakpia is that it is durable and not easily damaged. Under normal conditions, Bakpia can last up to one month without preservatives, if stored at normal room temperature (Ihsan, 2010).
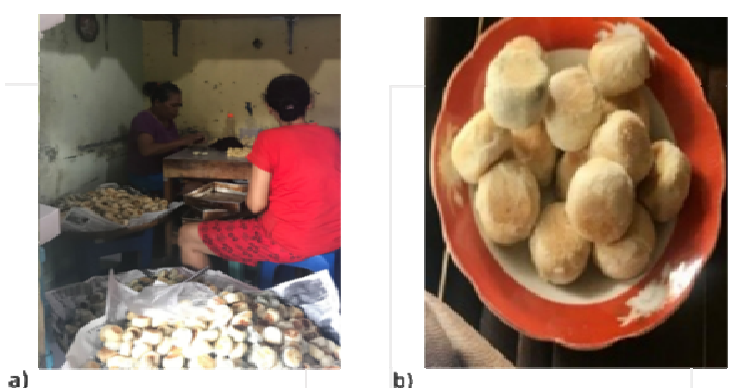

Note: a) The Employees are in the process of making Bakpia dough into small rounds

b) The Bakpia is ready to serve/pack.

Source: Research Documentation, 2019

Figure 3. The Process of Making Bakpia by Traditional Methods
This implicitly indicates that the demand for Bakpia in Yogyakarta has also decreased along with the decrease in the number of tourist attraction visits in Yogyakarta. Therefore, this is a challenge for the MSMEs operating in the tourism sector and the other sectors that support tourism, namely the MSMEs engaged in food and beverages, or other culinary specialties, in Yogyakarta. So the Bakpia MSMEs need to improve their innovation capabilities in order to improve their innovation performance, in the hope of encouraging the tourism sector in Yogyakarta.

Based on the above research gaps, this study examines the antecedents of innovation capability empirically, and its mediating role in improving the innovation performance of Bakpia MSMEs in Yogyakarta. The aims of this study are to identify and analyze the innovation capability dimensions of Bakpia MSMEs for their knowledge donating and collecting, and if they are able to support the improvement of their innovation capabilities, which should impact on 
their innovation performance. There are four objectives to support the aims: (1) Analyzing and identifying the influence of knowledge donating and collecting on innovation performance. (2) Analyzing and identifying the influence of knowledge donating and collecting on innovation capability. (3) Analyzing and identifying the influence of innovation capability on innovation performance. (4) Analyzing and identifying the mediation effect of innovation capability on improving innovation performance through knowledge donating and knowledge collecting.

Hence, the main contributions of this study are as follows. First, this study makes a theoretical contribution to innovation capability, influenced by knowledge sharing, including knowledge donating and knowledge collecting, and the implications for innovation performance. Second, this study is expected to provide a highly contextual meaning and specific technical implications that should be adopted by the MSMEs to improve their innovation capability, which should impact on their innovation performance.

\section{LITERATURE REVIEW AND HYPOTHESES DEVELOPMENT}

\section{Literature Review}

\subsection{Knowledge Sharing Process}

According to Liao et al. (2007) knowledge is an essential resource for preserving a valuable legacy, learning new techniques, solving problems, creating core competencies, and initiating new situations. The knowledge available from an organization is becoming an increasingly important resource (Van den Hooff $\&$ de Leeuw van Weenen, 2004; Van Den Hooff \& Ridder, 2004) and also the ability to manage knowledge is becoming increasingly important in this knowledge-based era (Dalkir, 2011).
Knowledge management is defined as obtaining the correct knowledge, or knowing where the valid sources of knowledge are, and being ready to get and give the relevant knowledge to the right people at the right time (Walsham, 2018). He also stated that competitive advantages, such as intellectual capital, can be developed through knowledge sharing. It can encourage the exchange and creation of knowledge in organizations. Sánchez et al. (2013) also stated that the main focus of knowledge management is knowledge sharing. Knowledge sharing is the key to responding immediately and proactively to a dynamic business environment (Almahamid et al., 2008). Knowledge sharing is a part of organizational life. The spontaneous and unstructured sharing of knowledge is necessary for company success. Even though the term "knowledge management" means formal sharing, the crucial element is developing particular strategies to encourage such spontaneous exchanges (Davenport \& Prusak, 1998).

According to Lin, (2007), knowledge sharing is socio-cultural communication, which includes exchanging knowledge, experiences, and the abilities of workers within entire departments or organizations. Knowledge sharing includes two actions; transmission (conveying the knowledge to the potential recipients) and absorption through that person or group. If knowledge is not absorbed, then it has not been transferred. That means just making knowledge available, not sharing it. The purpose of a knowledge transfer is to increase an organization's capacity to do something and increase its value (Davenport \& Prusak, 1998). Van Den Hooff \& Ridder (2004) argued that knowledge sharing is a process in which individuals exchange their knowledge (tacit and explicit knowledge) and create new knowledge. Based on this definition, the knowledge sharing process is made up of bringing (knowledge donating) and getting (knowledge 
collecting) (Lin, 2007; Van den Hooff \& de Leeuw van Weenen, 2004; Van Den Hooff \& Ridder, 2004; Yeşil et al., 2013), thus Van den Hooff \& de Leeuw van Weenen (2004); Van Den Hooff \& Ridder (2004) stated that the two activities must be distinguished as processes: either actively communicating what other individuals know, or actively consulting with other individuals to learn what they know. The two processes have different characteristics. Knowledge donating is the sharing of intellectual capital from individuals to other individuals or groups; meaning more costs than benefits, while knowledge collecting is allowing oneself to benefit from the intellectual capital of others, where a situation of benefit may be much greater than cost.

\subsection{Innovation Capability}

Terziovski (2007) stated "innovation is resources utilization to create value for the customer and the enterprise by developing, improving, and commercializing new and existing products, processes, and services." Meanwhile, Darmanto et al. (2015) stated that innovation could be interpreted as a process resulting from developing the application of knowledge, abilities, and experience to create or improve new products (goods and services), processes, and systems, which produce significant value. Innovation can also be defined as an "object"; it means a new product or practice that is available for use, commonly in a commercial context. The novelty level can be identified depending on the context, innovation can be new to a company, new to the market, or a country or region, or new holistically. Furthermore, innovation as an "activity" is a creative innovation process, and usually identified with copyright commercialization. Innovation can be interpreted from a different viewpoint, but the basis of innovation is a discovery that is different from the existing or previously known ones.
Innovation capability is essential to the long-term success of an organization. Innovation capability is also considered necessary for achieving superior innovation performance (Yeşil et al., 2013). Lawson \& Samson (2001) defined innovation capability as continuously changing knowledge and ideas into new products, processes, and systems to benefit a company and its stakeholders. Innovation capability will affect the configuration of new flows and critical activities that lead to the continuous innovation of products, processes, and systems. The more potent the firm's innovation capability, the more effective will be its innovation performance. Great companies invest in and maintain their innovation capability, from which they implement effective innovation processes, leading to innovations such as new products, services, processes, and excellent business performance results (Lawson \& Samson, 2001; Yeşil et al., 2013).

\subsection{Innovation Performance}

Many sources are related to innovation, but it is quite difficult to find studies on innovation performance. The definition of innovation performance can be explained as the capability to change innovation inputs into outputs. Thus it is the ability to transform innovation capability into market implementation. Innovation leading to market success can be achieved through innovative performance (Zizlavsky, 2016). Meanwhile, the measurement of innovation performance has attracted a great deal of interest from researchers and practitioners (Birchall et al., 2011). It is necessary to select the type of criteria used in the assessment to gauge the success of innovation performance (Zizlavsky, 2016). Tidd \& Bessant (2009) stated that the principle of innovation performance is to use what is known, or factors about successful and unsuccessful innovations and the conditions that cause them. Owners or managers can develop a 
list of questions and statements to ask an organization or company, and then can assess its performance against some of the "best practice" models and identify where things could be improved. In assessing innovation performance, some steps are more specific to the internal workings of the innovation process, or some aspects in it.

A previous study about measuring organizational innovation performance by Prajogo \& Ahmed (2006) built constructions to measure product and process innovation based on conceptualized criteria. These criteria were the number of innovations, the speed of innovation, the level of innovation (novelty or novelty of technological aspects), and being the first in the market. These four innovation characteristics are transformed into the innovation of products and processes.

\section{Hypotheses Development}

2.1. The influence of the Knowledge Sharing Process on Innovation Performance

Knowledge is the key to achieving sustainable innovation (Liao et al., 2007). Knowledge sharing among individuals in organizations is also fundamental to organizational innovation and success (Sánchez et al., 2013). Previous research by Ritala et al. (2015) showed that external knowledge sharing positively affected innovation performance. However, Jantunen et al. (2008) argued that knowledge sharing with horizontal and vertical parties insignificantly affected innovation performance. Another result from Yeşil et al. (2013) showed that the knowledge sharing process, which includes collecting and donating knowledge, does not affect innovation performance.

H1a: Knowledge donating has a positive and significant effect on innovation performance.

H1b: Knowledge collecting has a positive and significant effect on innovation performance.

The accumulated donation and collection of knowledge can create innovation capabilities which can improve the innovation performance of the MSMEs. This research examines if innovation performance can be achieved by the knowledge sharing process, which includes donating and collecting knowledge through innovation capability of MSMEs.

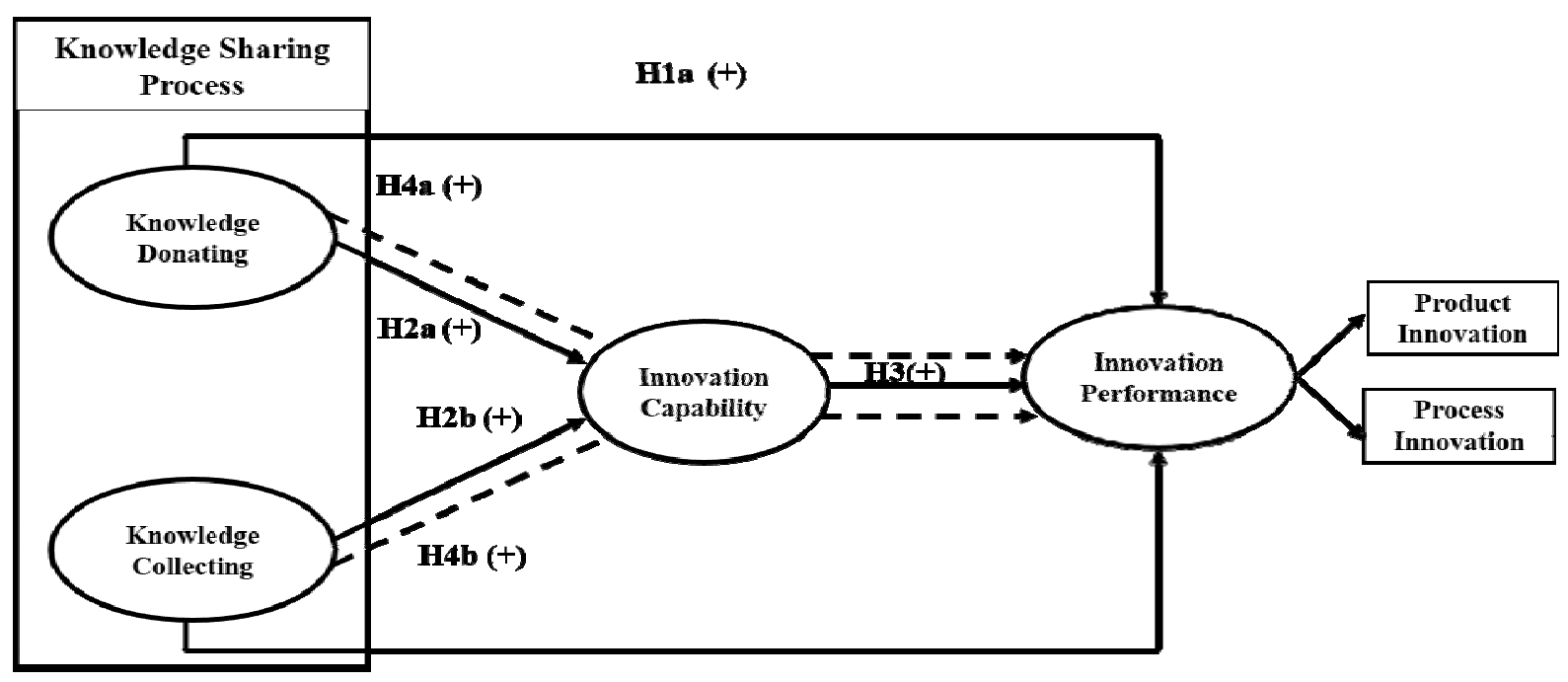

H1b (+)

Figure 4. Research Framework 
H4a: Knowledge donating has a positive and significant effect on innovation performance through innovation capability of MSMEs.

H4b: Knowledge collecting has a positive and significant effect on innovation performance through innovation capability of MSMEs.

2.2. The influence of the Knowledge Sharing Process on Innovation Capability

In this knowledge-intensive economic era, the knowledge available from organizations is becoming an increasingly important resource (Van den Hooff \& de Leeuw van Weenen, 2004; Van Den Hooff \& Ridder, 2004).

The main source for innovation includes knowledge that is created, transferred, and shared from individuals to other individuals or groups (Yeşil et al., 2013). The research result from Yeşil et al. (2013) showed that donating knowledge positively and significantly influenced innovation capability. However, innovation capability is insignificantly affected by knowledge collecting. The result from Lin (2007) showed that knowledge sharing, which includes knowledge donating and knowledge collecting, positively and significantly affected innovation capability. This research examines if the knowledge sharing process, including knowledge donating and knowledge collecting, can develop the innovation capability of the Bakpia MSMEs.

H2a: Knowledge donating positively and significantly affects innovation capability

$\mathrm{H} 2 \mathrm{~b}$ : Knowledge collecting positively and significantly affects innovation capability

2.3. The influence of Innovation Capability on Innovation Performance

Innovation capability provides the potential for effective innovation (Terziovski, 2007). Innova- tion capability is also considered essential to achieve superior innovation performance (Yeşil et al., 2013). If a company's innovation capability gets stronger, its innovation performance will be more effective (Lawson \& Samson, 2001). The research result from Prajogo \& Ahmed (2006) showed that innovation capability was positively related to innovation performance. Yeşil et al. (2013) stated that innovation capability positively and significantly affected innovation performance. Similar to the research conducted by Sözbilir (2018), innovation capability has a significant and positive impact on innovation performance. Utoyo et al. (2020) also found that the core innovation capabilities' configuration positively affected innovation performance. This research confirms that effective innovation performance can be achieved by innovation capability.

H3: Innovation capability positively and significantly affects innovation performance

\section{METHODOLOGY}

\section{Sample and Data collection}

This research's design was a survey with a quantitative method to test the hypotheses model. A survey was used to collect data by distributing questionnaires directly to Bakpia MSMEs in Yogyakarta. According to data from the Department of Trade and Industry, Yogyakarta, there are 103 Bakpia MSMEs in Yogyakarta. Data were collected using a purposive sampling technique on judgmental types. The judgmental sampling involves selecting research subjects who are in the most advantageous place or in the best position to provide information (Sekaran \& Bougie, 2013).

The subjects required to fill out the research questionnaire were the Bakpia MSMEs which carry out the production and marketing processes. The majority of the samples were taken in Pathuk and its surrounding areas. Based on 
the 103 Bakpia MSMEs in Yogyakarta there were some MSMEs that only acted as retailers. Because the measurement of the innovation capability variable emphasizes the ability of the production process to create new flavors, methods, and technology, Bakpia MSMEs which act as retailers were considered unsuitable. A total of 61 respondents who confirmed that produce and available via sms and whatsapp within two months. From the 61 questionnaires that were distributed, 48 were returned, which represented a response rate of $78.68 \%$. These were subsequently processed in order to obtain a description of the characteristics and perceptions of the Bakpia MSMEs in Yogyakarta.

Researchers used a partial least squares (PLS) analysis tools to test the research instruments. Due to the sample size not being very large, an evaluation of the model by a PLSSEM analysis was conducted using the SmartPLS 3.3.2 (Ganguly et al., 2019). The PLS-SEM approach can be used for very small samples, which means that the number of samples can be less than 100 (Hair, J. F. et al 2013). The evaluation of the measurement model or the outer model was carried out to assess the validity and reliability of the model (Chin, 1998). The outer model with reflexive indicators was evaluated through the convergent validity and discriminant validity of the latent constructforming indicators, along with composite reliability and Cronbach's alpha for the indicator block. The criteria used in this study to assess the validity with the outer loading was $\geq 0.5$ while the composite reliability and Cronbach's alpha were $>0.7$. The second evaluation of the structural model or inner model was by looking at the significance of the influence of the independent variable on the dependent variable, by looking at the p-value or t-statistic value. The p-value $<\alpha(5 \%$ or 1.96$)$ can be assumed to be significant (Ghozali \& Latan, 2015).

\section{Measurement}

A five-point Likert-type scale $(1=$ strongly disagree to $5=$ strongly agree) was used to measure the construct. Based on this research's framework, the knowledge sharing process, which included the donating and collecting of knowledge, was the predictor or antecedent variable.

The knowledge sharing process, which includes donating and collecting knowledge, was measured using six items adapted from Van Den Hooff \& Ridder (2004). The six items were: 1) MSMEs and internal parties learning about something new together. 2) MSMEs and internal parties sharing information. 3) MSMEs and internal parties sharing technical skills. 4) MSMEs and external parties learning about something new together. 5) MSMEs and external parties sharing information. 6) MSMEs and external parties sharing technical capabilities. These were used to measure the donation of knowledge, which assessed the degree to which the owners or managers of Bakpia MSMEs were willing to communicate or contribute intellectual capital (knowledge) to their employees and competitors. Furthermore, knowledge collecting was measured using four modified items, which assessed the employees' and competitors' activities in consultation with the owners or managers of the Bakpia MSMEs, regarding the intellectual capital they own. The four items were: 1) Collecting information which was within the internal scope of the MSMEs. 2) Documenting the technical capabilities of the MSMEs. 3) Collecting information by external parties (competitors). 4) Documenting the technical capabilities of the external parties (competitors) then shared to MSMEs.

On the other hand, innovation capability was a mediating variable, which was predicted to mediate between the knowledge sharing process and innovation performance. Innovation 
capability was measured using six items adapted from Calantone et al. (2002); Lin (2007); Sözbilir (2018); they were: 1) Trying new ideas. 2) Looking for new ways of doing things related to operational/ production activities. 3) Creative methods of operating. 4) Being the first to market new products and services. 5) Innovation considered too risky being rejected. 6) The introduction of new products increased over the past five years.

Based on this research framework, as illustrated in Figure 2, innovation performance is an endogen construct defined as the implication of innovation capability. Innovation performance was measured using nine items which consisted of product and process innovations adapted from Prajogo \& Ahmed (2006); and Sözbilir (2018), they were the following product innovation indicators: 1) novelty, 2) use of the latest technology, 3) product development speed, 4) number of new products, 5) the first product to enter the market (early market entrants), while the process innovation indicators were: 1) technological competitiveness, 2) adoptability the latest technology quickly, 3) the novelty of the technology used, 4) the rate of technological change.

\section{RESULT AND DISCUSSION}

Table 1 shows the characteristics of the respondents for the MSMEs, including the position of the respondent in MSMEs, the establishment year of MSMEs, the number of employees, and the turnover (per year). The descriptive analysis results showed that the respondents for the MSMEs were mostly the owners $(95.83 \%$ ), and $77.08 \%$ of the MSMEs were established more than ten years ago. Fortyeight (100\%) Bakpia MSMEs have less than ten employees, consisting of family members and neighbors of the owners or the managers. Based on the number of employees and turnover per year, it can be concluded that the Bakpia MSMEs in Yogyakarta are still classified as micro businesses.

In this study, the data were analyzed using PLS (partial least squares) by SmartPLS 3.3.2. Partial least squares (PLS) software or "projection to latent structures" is a variencebased SEM type created to solve the problems caused by SEM, based on covariance (Ghozali \& Latan, 2015).

Table 1. Characteristic of respondents and MSMEs

\begin{tabular}{clcc}
\hline & & Frequency & Percentage \\
\hline \multirow{2}{*}{ Position } & Owner & 46 & $95.83 \%$ \\
& Manager & 2 & $4.17 \%$ \\
Establishment & $<5$ years & 3 & $6.25 \%$ \\
& $5-10$ years & 8 & $16.67 \%$ \\
Number of & $>10$ years & 37 & $77.08 \%$ \\
Employees & $10-30$ & 48 & $100 \%$ \\
& $>30$ & 0 & 0 \\
Turnover & Rp0.00- Rp300,000,000.00 & 0 & 0 \\
(Per year) & $>$ Rp300,000,000.00- & 48 & $100 \%$ \\
& Rp2,500,000,000.00 & 0 & 0 \\
& $>$ Rp2,500,000,000.00- & & 0 \\
& Rp50,000,000,000.00 & 0 & \\
\hline
\end{tabular}




\section{Measurement Model (Outer Model)}

Figure 5 illustrates that the outer model's test results were the revised PLS algorithm test results that were used to evaluate the outer model through the validity test, and consisted of convergent and discriminant validity and also a reliability test.

\section{Convergent Validity}

A convergent validity test was undertaken by looking at the outer loading value and average variance extracted (AVE). According to Ghazali \& Latan (2015), the factor loading value or outer loading of the indicators, if between 0.5 and 0.6 , can still be considered as sufficient. It was accepted and is shown in Table 2 in bold. Also the (AVE) values for all the constructs must be $>$ 0.5 , which is shown in Table 3.

\section{Discriminant Validity}

Furthermore, the result of the discriminant validity test is shown by the cross loading values and square roots of the AVE. Cross loading values are shown in Table 2, and each construct's correlation with the indicator is higher than the correlation of the indicators with the other constructs. This meant that the latent construct can predict the indicator well, and it can be concluded as being valid. Also the square root of the AVE and the correlation between each construct must be higher than the correlation between the constructs in the model and this is shown in the Fornell \& Larcker criterion on the PLS algorithm test (Fornell \& Larcker, 1981). The bold elements in the matrix diagonals, shown in Table 3, indicate that the square root of the AVE in each construct was greater than the correlation between the construct and the other constructs. Then all the constructs in the revised model meet the adequate discriminant validity criteria.

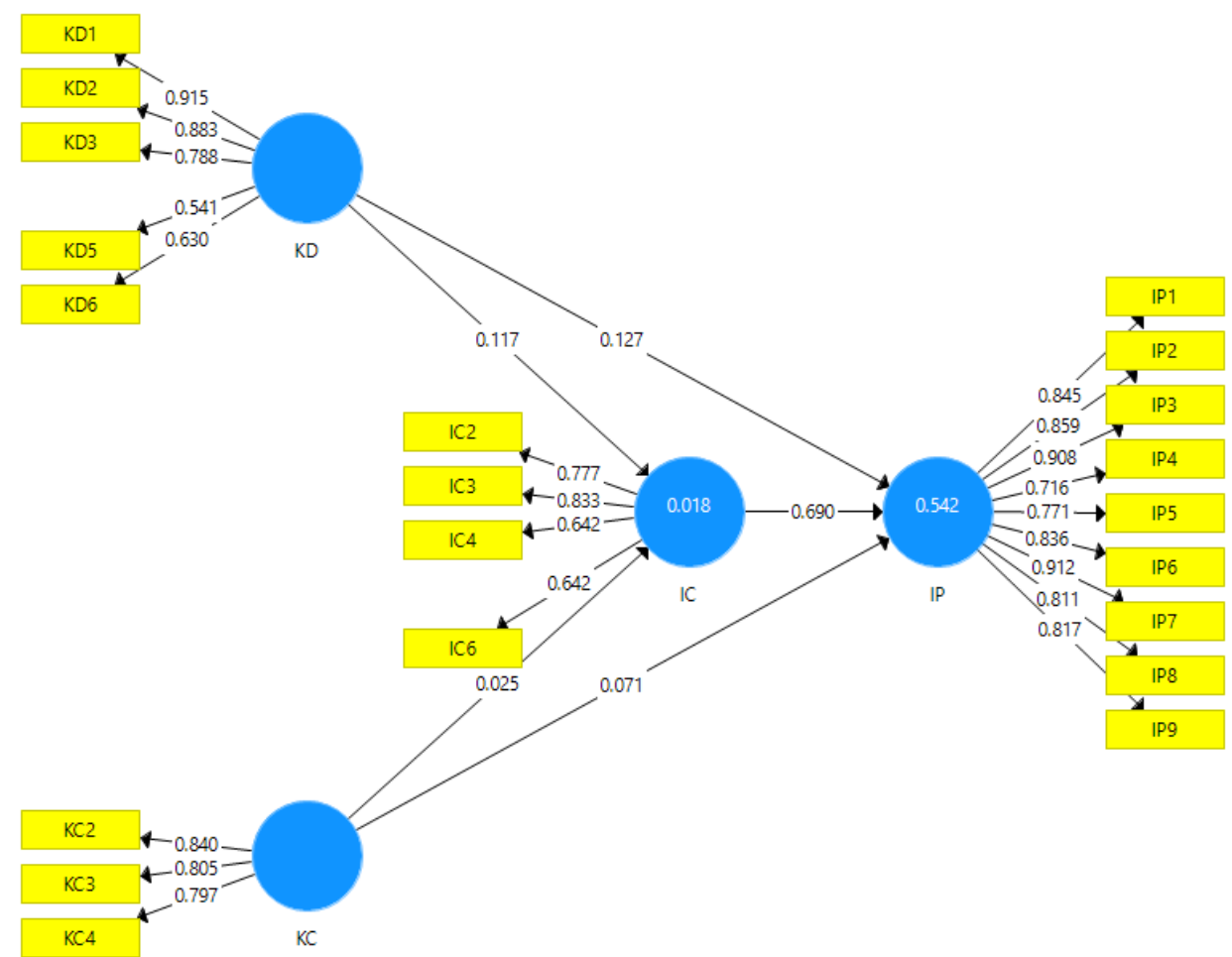

Note: (KD: Knowledge Donating; KC: Knowledge Collecting; IC: Innovation Capability; and IP: Innovation Performance)

Figure 5. PLS Algorithm Result 
Table 2. The Outer Loading and Cross Loading

\begin{tabular}{ccccc}
\hline & $\begin{array}{c}\text { Knowledge } \\
\text { Donating }\end{array}$ & $\begin{array}{c}\text { Knowledge } \\
\text { Collecting }\end{array}$ & $\begin{array}{c}\text { Innovation } \\
\text { Capability }\end{array}$ & $\begin{array}{c}\text { Innovation } \\
\text { Performance }\end{array}$ \\
\hline KD1 & $\mathbf{0 . 9 1 5}$ & 0.516 & 0.143 & 0.287 \\
KD2 & $\mathbf{0 . 8 3 3}$ & 0.483 & 0.061 & 0.220 \\
KD3 & $\mathbf{0 . 7 8 8}$ & 0.600 & 0.140 & 0.209 \\
KD5 & $\mathbf{0 . 5 4 1}$ & 0.376 & 0.032 & 0.067 \\
KD6 & $\mathbf{0 . 6 3 0}$ & 0.417 & 0.067 & 0.023 \\
KC2 & 0.674 & $\mathbf{0 . 8 4 0}$ & 0.079 & 0.220 \\
KC3 & 0.346 & $\mathbf{0 . 8 0 5}$ & 0.105 & 0.164 \\
KC4 & 0.406 & $\mathbf{0 . 7 9 7}$ & 0.009 & 0.066 \\
IC2 & 0.186 & 0.080 & $\mathbf{0 . 7 7 7}$ & 0.509 \\
IC3 & 0.254 & 0.199 & $\mathbf{0 . 8 3 3}$ & 0.600 \\
IC4 & -0.012 & -0.005 & $\mathbf{0 . 6 4 2}$ & 0.562 \\
IC6 & -0.004 & -0.056 & $\mathbf{0 . 6 4 2}$ & 0.363 \\
IP1 & 0.326 & 0.187 & 0.779 & $\mathbf{0 . 8 4 5}$ \\
IP2 & 0.060 & 0.057 & 0.544 & $\mathbf{0 . 8 5 9}$ \\
IP3 & 0.286 & 0.305 & 0.592 & $\mathbf{0 . 9 0 8}$ \\
IP4 & 0.047 & -0.070 & 0.556 & $\mathbf{0 . 7 1 6}$ \\
IP5 & 0.016 & 0.080 & 0.641 & $\mathbf{0 . 7 7 1}$ \\
IP6 & 0.231 & 0.192 & 0.555 & $\mathbf{0 . 8 3 6}$ \\
IP7 & 0.303 & 0.279 & 0.612 & $\mathbf{0 . 9 1 2}$ \\
IP8 & 0.178 & 0.180 & 0.487 & $\mathbf{0 . 8 1 1}$ \\
IP9 & 0.440 & 0.366 & 0.492 & $\mathbf{0 . 8 1 7}$ \\
\hline
\end{tabular}

\section{Reliability Test}

Meanwhile, the reliability test was conducted by looking at the value of the composite reliability, and Cronbach's alpha, which must be $>0.7$. The reliability test results, in Table 3 , showed that the composite reliability and Cronbach's alpha value were more than 0.7 ; which meant that all the constructs were reliable.

\section{Structural Model (Inner Model)}

The first step in testing the structural model was to test the goodness-of-fit of the research model, as shown by its $\mathrm{R}$-squared value $\left(\mathrm{R}^{2}\right)$. The results of the goodness-of-fit test in Figure 4 showed a moderate value for innovation performance, of 0.542 , and this meant that innovation performance can be explained

Table 3. Reliability Test Result

\begin{tabular}{lccccccc}
\hline & AVE & $\begin{array}{c}\text { Composite } \\
\text { Reliability }\end{array}$ & $\begin{array}{c}\text { Cronbach's } \\
\text { Alpha }\end{array}$ & $\begin{array}{c}\text { Knowledge } \\
\text { Donating }\end{array}$ & $\begin{array}{c}\text { Knowledge } \\
\text { Collecting }\end{array}$ & $\begin{array}{c}\text { Innovation } \\
\text { Capability }\end{array}$ & $\begin{array}{c}\text { Innovation } \\
\text { Performance }\end{array}$ \\
\hline $\begin{array}{l}\text { Knowledge } \\
\text { Donating }\end{array}$ & 0.586 & 0.872 & 0.843 & $\mathbf{0 . 7 6 5}$ & 0.621 & 0.132 & 0.263 \\
$\begin{array}{l}\text { Knowledge } \\
\text { Collecting }\end{array}$ & 0.663 & 0.855 & 0.772 & & $\mathbf{0 . 8 1 4}$ & 0.097 & 0.217 \\
$\begin{array}{l}\text { Innovation } \\
\text { Capability }\end{array}$ & 0.531 & 0.817 & 0.704 & & & 0.728 & \\
$\begin{array}{l}\text { Innovation } \\
\text { Performance }\end{array}$ & 0.693 & 0.953 & 0.944 & & & 0.714 & $\mathbf{0 . 8 3 2}$ \\
\hline
\end{tabular}


through the innovation capability by $54.2 \%$. Meanwhile, the $\mathrm{R}^{2}$ value of innovation capability was 0.018 , which was weak. So innovation capability can be explained through the construct of knowledge donating and knowledge collecting by only $1.8 \%$.

The second measurement was to evaluate the structural model to test the significance of all the hypotheses in this study. Acceptance or rejection of the hypothesis can be seen through: (1) tstatistic value and (2) the p-value. The significance level used in this study was $5 \%$ or 0.05 , so the significance value was 1.96 . The hypotheses can be accepted if the value of the tstatistic $>1.96$ and the $p$-value $<0.05$.

Figure 6 illustrated the results of testing the seven hypotheses and they are also summarized in Table 4. The influence of donating knowledge on innovation performance, as can be seen from the original sample value, was 0.127 (positive). However, the criteria for the value of the $t$ statistic was $0.699<1.96$ and the p-value was $0.485>0.05$. Furthermore, collecting knowledge on innovation performance, as can be seen in the original sample's value, was 0.071 (positive). However, the criteria for the value of the tstatistic was $0.463<1.96$ and the p-value was $0.644>0.05$, as shown in Table 4. So H1a and $\mathrm{H} 1 \mathrm{~b}$ were not supported. Likewise, the influence of knowledge donating on innovation capability, as can be seen from the original sample's value, was 0.117 (positive). However, the criteria for the t-statistic's value criteria was $0.531<1.96$ and the p-value was $0.595>0.05$. Furthermore, collecting knowledge on innovation capability, as can be seen from the original sample's value, was 0.025 (positive). However, the criteria for the value of the t-statistic was $0.120<1.96$ and the p-value was $0.905>0.05$. So $\mathrm{H} 2 \mathrm{a}$ and $\mathrm{H} 2 \mathrm{~b}$ were also not supported. However, the hypotheses testing showed that innovation capability positively and significantly influenced innovation performance. It can be seen from the original sample's value, which was 0.690 (positive), and also from the criteria for the value of the t-statistic, which was $8.301>1.96$ and the p-value was $0.000<0.05$. Thus, H3 was supported.

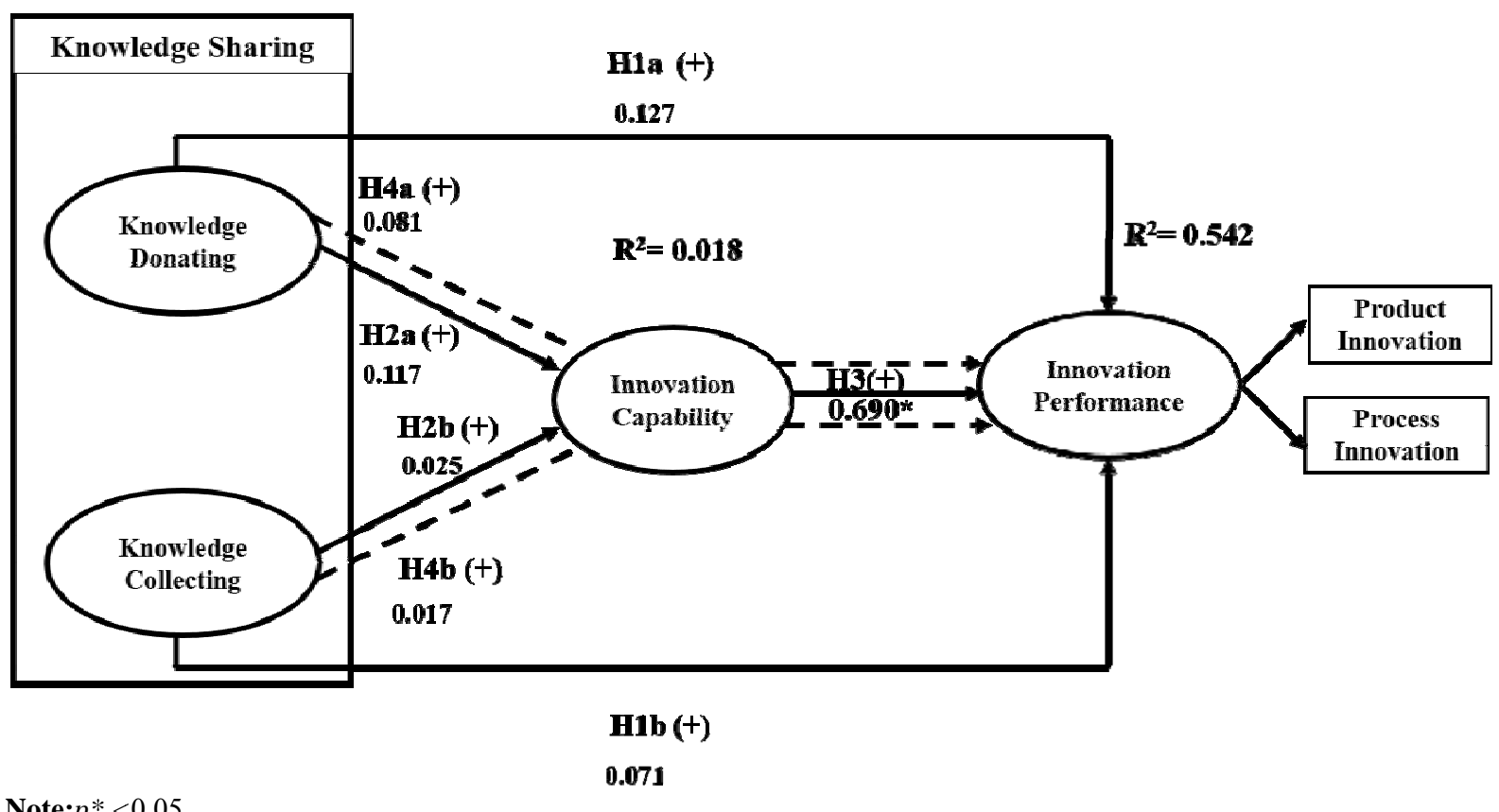

Figure 6. Structural Model Result 
Furthermore, the indirect effect of knowledge donating on innovation performance through innovation capability showed an insignificant effect. It can be seen from the original sample's value of 0.081 (positive), but the t-statistic value was $0.527<1.96$ and the p-value was $0.599>$ 0.05 . Likewise, the influence of knowledge collecting on innovation performance through innovation capabilities also showed an insignificant effect. It can be seen from the original sample's value of 0.017 (positive), but the t-statistic value was $0.119<1.96$ and the p-value was $0.906>0.05$. So H4a and H4b were rejected.

\section{Discussion}

The hypotheses testing in this study used the direct effect and indirect effect testing methods. Testing the direct effect to test hypotheses H1a, $\mathrm{H} 1 \mathrm{~b}, \mathrm{H} 2 \mathrm{a}, \mathrm{H} 2 \mathrm{~b}$ and $\mathrm{H} 3$ was done by looking at the p-values. Testing the indirect effect involved testing the role of the mediation which was the influence between the antecedent variable on the dependent variable through the mediator variable. In this study, innovation capability was a variable that was suspected of being a mediator. Testing the indirect effect to test hypotheses $\mathrm{H} 4 \mathrm{a}, \mathrm{H} 4 \mathrm{~b}$ was done by looking at the p-values.

The testing of Hypothesis H1a indicated that donating knowledge positively and insignificantly affected innovation performance. It can be seen from the original sample of 0.127 (positive), but the p-value was $0.485>0.05$. The result of testing H1b also showed that collecting knowledge positively and insignificantly affected innovation performance, as shown in Table 4, the original sample value was 0.071 (positive). However, the p-value result was 0.644 , which was not expected, as it was more than 0.05 . These implied a greater willingness to undertake the knowledge sharing process, which included donating and collecting knowledge. This would increase the innovation performance of the Bakpia MSMEs in Yogyakarta even if the increase was not significant. These results confirmed the previous study by Yeşil et al., (2013).

Table 4. Structural Model Result

\begin{tabular}{|c|c|c|c|c|c|c|}
\hline & $\begin{array}{c}\text { Original } \\
\text { Sample }(O)\end{array}$ & $\begin{array}{c}\text { Sample } \\
\text { Mean (M) }\end{array}$ & $\begin{array}{l}\text { Standard } \\
\text { Deviation } \\
\text { (STDEV) }\end{array}$ & $\begin{array}{c}\text { T Statistic } \\
(|O / S T D E V|)\end{array}$ & $P$ Values & Result \\
\hline $\begin{array}{l}\text { Knowledge Donating } \rightarrow \\
\text { Innovation Performance }\end{array}$ & 0.127 & 0.090 & 0.182 & 0.699 & 0.485 & $\begin{array}{c}\text { Not } \\
\text { Supported }\end{array}$ \\
\hline $\begin{array}{l}\text { Knowledge Collecting } \rightarrow \\
\text { Innovation Performance }\end{array}$ & 0.071 & 0.098 & 0.154 & 0.463 & 0.644 & $\begin{array}{c}\text { Not } \\
\text { Supported }\end{array}$ \\
\hline $\begin{array}{l}\text { Knowledge Donating } \rightarrow \\
\text { Innovation Capability }\end{array}$ & 0.117 & 0.146 & 0.220 & 0.531 & 0.595 & $\begin{array}{c}\text { Not } \\
\text { Supported }\end{array}$ \\
\hline $\begin{array}{l}\text { Knowledge Collecting } \rightarrow \\
\text { Innovation Capability }\end{array}$ & 0.025 & 0.050 & 0.205 & 0.120 & 0.905 & $\begin{array}{c}\text { Not } \\
\text { Supported }\end{array}$ \\
\hline $\begin{array}{l}\text { Innovation Capability } \rightarrow \\
\text { Innovation Performance }\end{array}$ & 0.690 & 0.693 & 0.083 & 8.301 & $0.000 *$ & Supported \\
\hline $\begin{array}{l}\text { Knowledge Donating } \rightarrow \\
\text { Innovation Capability } \rightarrow \\
\text { Innovation Performance }\end{array}$ & 0.081 & 0.097 & 0.153 & 0.527 & 0.599 & $\begin{array}{c}\text { Not } \\
\text { Supported }\end{array}$ \\
\hline $\begin{array}{l}\text { Knowledge Collecting } \rightarrow \\
\text { Innovation Capability } \rightarrow \\
\text { Innovation Performance }\end{array}$ & 0.017 & 0.034 & 0.143 & 0.119 & 0.906 & $\begin{array}{c}\text { Not } \\
\text { Supported }\end{array}$ \\
\hline
\end{tabular}


The testing of Hypothesis H2a showed that knowledge donating had positive but insignificant effects on innovation capability. It can be seen from the original sample of 0.117 (positive), but the p-value was 0.595 , which is more than 0.05 . Hypothesis H2a contradicts the previous study by Yeşil et al. (2013), and Lin (2007), who found that donating knowledge positively and significantly affected innovation capability; the willingness of employees to donate and collect knowledge allowed companies to increase their innovation capability. Employees' knowledge sharing was primarily caused by a willingness to donate knowledge to other co-workers, rather than collecting knowledge from others (Liao et al., 2007). Furthermore, H2b also showed that knowledge collecting positively and insignificantly affected innovation capability; as shown in Table 4, the original sample value was 0.025 (positive). Still, the $\mathrm{p}$-value was $0.905>0.05$. H2b confirmed the previous research by Yeşil et al. (2013), that knowledge collecting did not significantly influence innovation capability. Hypotheses testing of $\mathrm{H} 2 \mathrm{a}$ and $\mathrm{H} 2 \mathrm{~b}$ showed that knowledge donating and collecting had a positive effect on innovation capability but it was not significant. That implied a greater willingness to undertake a knowledge sharing process, which included donating and collecting knowledge. It would increase the ability of Bakpia MSMEs in Yogyakarta to innovate. However, the antecedent variables were not significant in influencing the innovation capability. So, the hypotheses testing results of the direct effect on hypotheses H1a, H1b, H2a, and H2b show they are not supported.

There are differences in research analysis unit, this study focused on MSMEs, which made it different from the previous research conducted by Yeşil et al., (2013) which has a research background in operating firm in several sectors, including the food sector, also has more or equal to thirty employees, including having professional employees. MSMEs and big companies each have different characteristics. The differences can be seen in their knowledge of human resources, how to produce successfully, and their use of technology. Human resources are an important component of organizations. Human resources in an organization include all the parties (internal and external) that contribute to an organization, including the owners, managers, employees, and competitors (external). The knowledge and abilities of the human resources in an organization will determine the success of that organization. In today's knowledge-intensive economy, the knowledge available from an organization has become an increasingly important resource (Van den Hooff \& de Leeuw van Weenen, 2004; Van Den Hooff \& Ridder, 2004). An individual's knowledge is also often linked to their level of education. Human resources in big companies can often have a higher education level than human resources in MSMEs. It is known that the majority of Bakpia MSMEs in Yogyakarta have been around for more than 10 years now. This may mean that their human resources, including the owners, managers, employees, and competitors, do not have a very high level of education. One of the obstacles to introducing performance measurements in MSMEs is the lack of financial and human resources (exogenous barriers) (Curraj, 2018; Garengo et al., 2005).

Apart from their human resources being seen as lacking high levels of education, knowledge can also be obtained through previous experience through organizational learning. Bakpia MSMEs can survive in the business environment in general, and in the food and beverage sector in particular. MSMEs mostly acquire knowledge through experience and it is often absorbed by tacit learning in organizational learning (Ates et 
al., 2013; Garengo et al., 2005). In Bakpia MSMEs, knowledge is obtained through sharing experiences and skills among themselves. The knowledge sharing process includes knowledge donating and collecting, usually done by the owners and managers on a person-to-person basis during routine meetings of the MSME association, or certain groups outside the meeting. The owners and managers of Bakpia MSMEs share their knowledge through knowledge donating and knowledge collecting activities; these can encourage the knowledge exchange and creation of Bakpia MSMEs. Meanwhile, according to Ackerman et al. (2003), regarding the organizational learning process, knowledge sharing can be analyzed as consisting of these three knowledge-sharing activities: externalizing individual knowledge, so that knowledge becomes communicated; objectifying this knowledge into organizational knowledge so that knowledge is taken for granted; internalizing this organizational knowledge by the organization's members. Furthermore, the activities of knowledge sharing are bringing (knowledge donating) and getting (knowledge collecting) (Lin, 2007; Van Den Hooff \& Ridder, 2004; Yeşil et al., 2013)

Knowledge donating aims to see an individual's knowledge spread and changed into group knowledge and organizational knowledge over time, which in turn will increase the stock of knowledge available to Bakpia MSMEs through the following indicators: learning something new with employees (internal) and competitors (external), sharing information with employees, and sharing a technical skill with employees and competitors. Bakpia MSME owners and managers, who are members of associations or groups, actively donate their knowledge. Meanwhile, the Bakpia MSME owners and managers who do not attend meetings or who are not association members do little to contribute or donate knowledge. It is known that there are Bakpia MSME owners and managers who are reluctant to pass on knowledge to their employees (if they are not from their families) and competitors because they think that what they learn and the information they have is a company secret. However, knowledge sharing depends on each individual's degree of willingness to share knowledge. It is unfortunate that some individuals tend to hoard knowledge and are reluctant to share their key knowledge because they are afraid of losing ownership of the knowledge and the related loss of power (Alsharo et al., 2017; Kankanhalli et al., 2005; Lei et al., 2019).

A company does not want to share everything it knows with its collaborative partners, as this could hinder the benefits from its innovations (Ritala et al., 2015). As seen in the result of observations by Ackerman et al. (2003) people seem to refuse to share their knowledge. Knowledge sharing enhances the vulnerability of those who share it. It means sharing secrets that are kept individually with other individuals or groups. However, Bakpia MSME owners and managers are more open to donating knowledge about their techniques or production methods to their employees and competitors. They are good at choosing and sorting which information is appropriate or inappropriate to share with their employees and competitors.

However, knowledge collecting consists of processes and mechanisms to collect information and knowledge from internal and external sources; the internal sources are the employees and the external source their competitors. Bakpia MSMEs implement knowledge collecting, including documenting any technical capabilities of the MSMEs and the competitors who distribute to MSMEs, and also collect information from competitors. The knowledge collecting 
process, in which organizational knowledge becomes group and individual knowledge, involves the internalization and dissemination of knowledge. Internalization and outreach take a long time, meaning that the accumulation of knowledge obtained through knowledge collecting takes a long time to produce or achieve an effective innovation capability and innovative performance. Accumulating knowledge means enabling oneself to profit from the intellectual capital of others. But, on the other hand, since the knowledge is mainly tacit and context-specific, the information that is required to implement and use a performance measurement is difficult to collect (Garengo et al., 2005).

There are many differences in taste, texture, and aroma of Bakpia because every MSMEs has a principle in making Bakpia. Each Bakpia MSMEs has its own methods and recipes that are considered the most correct and used as their respective guidelines for making Bakpia. They get methods/techniques and dough from hereditary recipes since the establishment of the Bakpia MSMEs, which are then developed. Based on the MSMEs' characteristics, most of them were established more than 10 years ago. Therefore, their owners and managers are very good at maintaining the production methods used for so long. Usually, the managers of MSMEs have multiple roles and are responsible for both the operational and strategic functions (Ates et al., 2013; Garengo et al., 2005). However, Bakpia MSMEs owners and managers do not shut themselves off from accepting suggestions from their employees and competitors. Some of the advice they are given is about ideas for new flavors and new techniques for making Bakpia.

The result of testing Hypothesis H3 showed that innovation capability positively and significantly affected innovation performance, as shown in Table 4 . The original sample value was
0.690 (positive), and the p-value was $0.000<$ 0.05. It can be concluded that Hypothesis $\mathbf{H 3}$ is supported. It implies that a higher innovation capability will lead to better innovation performance. This result confirmed the previous research by Prajogo \& Ahmed (2006); Sözbilir (2018); Yeşil et al. (2013), who stated that innovation capability affected innovation performance positively and significantly. The companies' innovation capability allowed them to find new systems, develop new products and services quickly, and market them (Sözbilir, 2018). The findings showed that Bakpia MSME owners and managers actively find new ways to do things, related to their production activities, through the media, their employees, and their competitors. However, Bakpia MSME owners and managers who have entered the unproductive age $(\geq 65)$ are passive in finding new ways to produce and stick with their old ways of producing. Besides, Bakpia MSME owners and managers show many creative abilities in their practices of producing Bakpia. They make continuous and periodic small improvements in determining the quantities used in their Bakpia recipe, including creating new flavor variants, and using new cooking methods, tools or machines (traditional to semi-modern), and packaging. So it can be seen that Bakpia MSMEs are implementing incremental innovations to improve innovation performance. Small food enterprises are mainly concerned with incremental product and process innovations with a low rate of radical innovations (Avermaete, 2002; Baregheh et al., 2012). Incremental innovation occurs continuously within organizations and leads to small improvements in their products or processes (Terziovski, 2007).

The following are the results of hypothesis testing for the indirect effect of $\mathrm{H} 4 \mathrm{a}$ and $\mathrm{H} 4 \mathrm{~b}$. Hypothesis H4a testing showed that knowledge 
donating had a positive effect but did not significantly influence innovation performance mediated by innovation capability. The original sample of H4a was 0.081 (positive). But, the pvalue was $0.599>0.05$. Furthermore, Hypothesis $\mathrm{H} 4 \mathrm{~b}$ indicated that knowledge collecting was positive but did not significantly influence innovation performance mediated by innovation capability. The original sample of $\mathrm{H} 4 \mathrm{~b}$ was 0.017 (positive), but the p-value was $0.906>$ 0.05 . It can be concluded from the hypotheses' testing results that H4a and $\mathbf{H 4 b}$ are not supported.

It is known that the innovation capability of Bakpia MSMEs in Yogyakarta was insignificant for mediating the knowledge donating and knowledge collecting to innovation performance.

It happened because the ability to share knowledge requires comprehensive skills that involve both soft skills and hard skills. The fact is that the knowledge donated and collected by Bakpia MSMEs in Yogyakarta has not been fully absorbed, so that it has not been able to significantly increase their ability to innovate. The use of technology such as the internet for data mapping and also the ability to analyze relevant and strategic data to support their innovation capability improvements is still very minimal at the MSME level. MSMEs are not always capable of adopting new ways of acting and new techniques because they lack the time, resources, and know-how to develop their operations (Curraj, 2018; Garengo et al., 2005).

Innovation capability has a different measurement from donating and collecting knowledge. The antecedents did not strongly influence innovation capability, but the antecedent's constructs can still build and develop innovation capability. Based on the findings of research from Sulistiyani \& Harwiki (2016), the innovation capabilities of MSMEs can be improved by establishing knowledge sharing behavior between their owners and employees, and between the owners in clusters (competitors). But in this study, it is known that Bakpia MSMEs actively implement knowledge sharing processes even though they do not significantly affect their innovation capability and innovation performance, because knowledge-based innovation has the longest lead time of all innovations, since the first thing is that there is a long time between the development of new knowledge and its application in new technology. Then there is another long period before the new technology transforms into a new product, process, or service in the market. The second thing is that knowledge-based innovation is seldom based on one factor but sits at the confluence of several types of knowledge, not all of it scientific or technological (Drucker, 2002). In addition to the limited skills of the employees of MSMEs, the managers or owners often do not have enough managerial expertise, which can result in the lack of solid strategic business planning and human resource management that will have negative impacts on the MSMEs' operations (Curraj, 2018).

There may be other constructs that encourage Bakpia MSMEs to increase their ability to innovate. The factors that can build innovation capability, according to Lawson \& Samson (2001), are: 1) vision \& strategy; 2) making use of basic competencies; 3) intelligence of organization; 4) creativity and idea management; 5) structure \& systems; 6) culture and climate; 7) management of technology. A learning process is needed to find out how capabilities develop over time. It is not enough to have only good or bad experiences. The key is to evaluate and reflect, and then develop the organization so it is ready when business challenges arise (Terziovski, 2007) 


\section{CONCLUSION AND IMPLICATION}

Based on the result and discussion, it is known that the knowledge sharing process, which includes knowledge donating and knowledge collecting, has a positive but insignificant effect on innovation performance. So the Bakpia MSMEs need to manage knowledge in order to respond quickly and proactively to changes in the business environment in general, and specifically in the food sector. Bakpia MSMEs owners and managers, as the drivers of their employees, must take a proactive stance in improving the knowledge sharing process directly through community or group meetings, or indirectly through electronic and print media. Bakpia MSMEs owners and managers should increase their willingness to donate knowledge through "pulling" activities: finding sources of knowledge on how to produce Bakpia so that they are effective and efficient by utilizing available local resources. Sources of knowledge can be found in libraries, seminars from experts, and collaborating with other Bakpia MSMEs owners. Then, the source of knowledge that contains the data and information is donated to the employees and owners of other Bakpia MSMEs. So, through this knowledge donating activity, Bakpia MSMEs employees and competitors can absorb the knowledge that has been donated by their owners and managers. Bakpia MSMEs owners and managers are also advised to evaluate each production step taken by their employees, to find out whether the donated knowledge has been adequately absorbed or not. The owner must trust the employees and competitors to donate the knowledge. Meanwhile, the owners must also try to apply organizational learning at Bakpia MSMEs to improve their knowledge collecting activities. This means that not only the owners and managers of Bakpia MSMEs take part in the knowledge sharing process activities, but the employees and competitors also have to participate in the knowledge sharing process through active organizational learning. When Bakpia MSMEs owners and managers ask questions of their employees, it is expected that the employees will also actively inform the owners and managers. This can trigger the process of creating new knowledge. If the knowledge sharing process, which includes knowledge donating and knowledge collecting can be improved through several of the methods that have been suggested above, that it will be enough to increase the ability of Bakpia MSMEs to innovate significantly.

On the other hand, it is known that innovation capability has a positive and significant effect on innovation performance. In this study it has been shown that the indicators that build the innovation capability of Bakpia MSMEs are: 1) looking for new ways of doing things related to operational / production activities; 2) being creative in operating methods; 3) being the first to market new products and services; and 4) new product introductions have increased over the past five years. The ability to innovate by Bakpia MSMEs must be maintained and improved so that innovation performance also increases continuously and significantly. Innovation capability can be improved through several things, including: periodically evaluating strategies; improving communication between owners, managers, and employees; enhancing creativity and ideas' management; improving the management of technology in MSMEs; give awards or rewards to employees in appreciation of their performance to advance Bakpia MSMEs. Furthermore, Bakpia MSMEs should try to reduce their ambiguity in implementing production activities to a manageable level through effective information management and tighter controls. Another result shows that the 
knowledge sharing process, which includes knowledge donating and knowledge collecting, has a positive but insignificant effect on innovation performance mediated by innovation capability. This means that innovation capability is considered not strong enough to mediate the knowledge donating and knowledge collecting and innovation performance. This is because of the antecedents of innovation capability, namely knowledge sharing, which includes knowledge donating and knowledge collecting, does not strongly affect innovation capability. On the other hand, innovation capability has a different measurement from the antecedents. Therefore, the above efforts are needed to improve innovation capability and its antecedents.

\section{REFERENCES}

Ackerman, M. S., Pipek, V., \& Wulf, V. (2003). Expertise Sharing: Beyond knowledge management. In Massachusetts Institute of Technology Press.

https://doi.org/10.7551/mitpress/6208.003.0 019

Almahamid, S., Hussein, A., \& Talal, B. (2008). Annual Conference La Jolla, California, U.S.A May 9 to May 12, 2008 1. 1-20.

Alsharo, M., Gregg, D., \& Ramirez, R. (2017). Virtual team effectiveness: The role of knowledge sharing and trust. Information and Management, 54(4), 479-490. https://doi.org/10.1016/j.im.2016.10.005

Ates, A., Garengo, P., Cocca, P., \& Bititci, U. (2013). The development of SME managerial practice for effective performance management. Journal of Small Business and Enterprise Development, 20(1), 28-54.

https://doi.org/10.1108/1462600131129840 2

Avermaete, T. (2002). Systems of innovation: The case of small food firms in the EU. Journal of Chemical Information and Modeling, 53(9), 1689-1699.
Baregheh, A., Rowley, J., Sambrook, S., \& Davies, D. (2012). Food sector SMEs and innovation types. British Food Journal, 114(11), 1640-1653. https://doi.org/10.1108/0007070121127312 6

Birchall, D., Chanaron, J. J., Tovstiga, G., \& Hillenbrand, C. (2011). Innovation performance measurement: Current practices, issues and management challenges. International Journal of Technology Management, 56(1), 1-20.

https://doi.org/10.1504/IJTM.2011.042492

Calantone, R. J., Cavusgil, S. T., \& Zhao, Y. (2002). Learning orientation, firm innovation capability, and firm performance. Industrial Marketing Management, 31(6), 515-524. https://doi.org/10.1016/S00198501(01)00203-6

Chin, W. W. (1998). The partial least squares approach for structural equation modeling. Modern Methods for Business Research, January 1998, 295-336.

Chuluun, T., Prevost, A., \& Upadhyay, A. (2017). Firm network structure and innovation. Journal of Corporate Finance, 44, 193-214.

https://doi.org/10.1016/j.jcorpfin.2017.03.00 9

Curraj, E. (2018). Business digitalization of SMEs in Albania: Innovative approaches and their impact on performance. Phd Thesis, October, 1-190.

Darmanto, Wardoyo, F. S., \& Dwiyani, T. (2015). Bauran Orientasi Strategi dan Kinerja Organisasi: Penerapan Variabel Anteseden, Moderasi dan Mediasi dalam Penelitian Ilmiah. [Strategy orientation mix and organizational performance: Application of antecedent variables, moderation in scientific research]. Yogyakarta: Deepublish.

Davenport, Thomas H. \& Prusak, Laurence. Working knowledge: how organizations manage what they know. (1998). In Choice Reviews Online (Vol. 35, Issue 09). https://doi.org/10.5860/choice.35-5167 
Dereli, D. D. (2015). Innovation Management in Global Competition and Competitive Advantage. Procedia - Social and Behavioral Sciences, 195, 1365-1370. https://doi.org/10.1016/j.sbspro.2015.06.323

Dinas Pariwisata Daerah Istimewah Yogyakarta. (2017). Statistik Kepariwisataan 2017. [Tourism Statistics 2017] Dinas Pariwisata DIY, xiv, xv, 6 .

Dinas Pariwisata Daerah Istimewah Yogyakarta. (2018). Statistik Kepariwisataan 2018. [Tourism Statistics 2018]. Dinas Pariwisata DIY.

Dinas Pariwisata Daerah Istimewah Yogyakarta. (2019). Statistik Kepariwisataan 2019. [Tourism Statistics 2019]. Dinas Pariwisata DIY.

Drucker, P.F. (2002). Innovation and entrepreneurship: Practice and principles: Harper \& Row.

Fornell, C., \& Larcker, D. F. (1981). Evaluating structural equation models with unobservable variables and measurement error. Journal of Marketing Research, 18(1), $39-50$.

Ganguly, A., Talukdar, A., \& Chatterjee, D. (2019). Evaluating the role of social capital, tacit knowledge sharing, knowledge quality and reciprocity in determining innovation capability of an organization. In Journal of Knowledge Management (Vol. 23, Issue 6). https://doi.org/10.1108/JKM-03-2018-0190

Garengo, P., Biazzo, S., \& Bititci, U. S. (2005). Performance measurement systems in SMEs: A review for a research agenda. International Journal of Management Reviews, 7(1), 25-47.

https://doi.org/10.1111/j.1468-

2370.2005.00105.x

Ghozali, I., \& Latan, H. (2015). Partial least squares: Konsep, teknik, dan aplikasi menggunakan program smartPLS 3.0. [Partial least squares: Concepts, techniques, and applications using the smartPLS 3.0 program]. Semarang: UNDIP.

Hair, J. F., Hult, G. T. M., Ringle, C. M., \&
Sarstedt, M. (2013). A Primer on Partial Least Squares Structural Equation Modeling (PLS-SEM). Thousand Oaks. Sage, 165.

Ihsan, A. (2010). Usaha camilan modal < 1 juta balik modal 1 bulan. [Snack business with the capital $<1$ million can turnover in 1 month]. Yogyakarta: Grhatama.

Jantunen, A., Puumalainen, K., \& HurmelinnaLaukkanen, P. (2008). Knowledge sharing and innovation performance. Journal of Information and Knowledge Management, 7(3), 187-195.

https://doi.org/10.1142/S021964920800205 6

Kankanhalli, A., Tan, B. C. Y., \& Wei, K.-K. (2005). Contributing knowledge to electronic knowledge repositories. An Empirical Investigation, 29(1), 113-143. http://www.scopus.com/inward/record.url?s $\mathrm{cp}=28744434462 \&$ partnerID $=8$ YFLogxK $\%$ 0Ahttps://www.scopus.com/record/pubmetri cs.uri?eid=2-s2.0-

28744434462\&origin=recordpage

Dalkir, K. (2011). Book Knowledge Management in Theory and Practice. In 2011, 485 p.: ill.., Cambridge, Mass.: MIT Press, Cambridge, Mass. Cambridge, Mass. : MIT Press, Cambridge, Mass.

http://site.ebrary.com/lib/unimannheim/doc Detail.action?docID=10476096

Koperasi, P., \& DIY, U. K. M. (2017). Perkembangan koperasi \& ukm diy. 17.

Lawson, B., \& Samson, D. (2001). Developing Innovation Capability In Oorganization : A Dynamic. International Journal of Innovation Management, 5(3), 377-400.

Lei, H., Nguyen, T. T., \& Le, P. B. (2019). How knowledge sharing connects interpersonal trust and innovation capability: The moderating effect of leadership support. Chinese Management Studies, 13(2), 276298. https://doi.org/10.1108/CMS-06-20180554

Liao, S. H., Fei, W. C., \& Chen, C. C. (2007). Knowledge sharing, absorptive capacity, and innovation capability: An empirical 
study of Taiwan's knowledge-intensive industries. Journal of Information Science, 33(3), 340-359. https://doi.org/10.1177/0165551506070739

Lin, H. F. (2007). Knowledge sharing and firm innovation capability: An empirical study. International Journal of Manpower, 28(34), 315-332.

https://doi.org/10.1108/0143772071075527 2

Prajogo, D. I., \& Ahmed, P. K. (2006). Relationships between innovation stimulus, innovation capacity, and innovation performance. $R$ and D Management, 36(5), 499-515. https://doi.org/10.1111/j.14679310.2006.00450.x

Rajapathirana, R. P. J., \& Hui, Y. (2018). Relationship between innovation capability, innovation type, and firm performance. Journal of Innovation and Knowledge, 3(1), 44-55.

https://doi.org/10.1016/j.jik.2017.06.002

Ritala, P., Olander, H., Michailova, S., \& Husted, K. (2015). Knowledge sharing, knowledge leaking and relative innovation performance: An empirical study. Technovation, 35, 22-31.

https://doi.org/10.1016/j.technovation.2014. 07.011

Sánchez, J. H., Sánchez, Y. H., Collado-Ruiz, D., \& Cebrián-Tarrasón, D. (2013). Knowledge Creating and Sharing Corporate Culture Framework. Procedia - Social and Behavioral Sciences, 74, 388-397. https://doi.org/10.1016/j.sbspro.2013.03.029

Sekaran, U. \& Bougie, R. (2013). Research methods for business: a skill-building approach. Chichester: John Wiley \& Sons Ltd.

Sözbilir, F. (2018). Innovation Capacity and Innovation Performance in Terms of Educational Level of Managers. Journal of Business Research - Turk, 10(2), 1-12. https://doi.org/10.20491/isarder.2018.415

Sugondo, S., (2019, September 19). Kota Yogyakarta memiliki 40 persen industri kreatif sektor pangan dan minuman. [Yogyakarta has 40 (fourty) percent of the creative industry in the food and beverage sector]. Jogja Inside. Retrieved from https://jogjainside.com/Kota-yogyakartamemiliki-40-persen-industri-kreatif-sektorpangan-dan-minuman/

Sulistiyani, R., \& Harwiki, W. (2016). How SMEs Build Innovation Capability Based on Knowledge Sharing Behavior? Phenomenological Approach. Procedia - Social and Behavioral Sciences, 219, 741-747. https://doi.org/10.1016/j.sbspro.2016.05.070

Terziovski, M. (2007). Building Innovation Capability in Organizations: An International Cross-Case Perspective.

Tidd, J., \& Bessant, J. (2009). Managing Innovation: Integrating Technological, Market and Organizational Change. In Journal of Chemical Information and Modeling.

Utoyo, I., Fontana, A., \& Satrya, A. (2020). The role of entrepreneurial leadership and configuring core innovation capabilities to enhance innovation performance in a disruptive environment. International Journal of Innovation Management, 24(6). https://doi.org/10.1142/S136391962050060 7

Van den Hooff, B., \& de Leeuw van Weenen, F. (2004). Committed to share: Commitment and CMC use as antecedents of knowledge sharing. Knowledge and Process Management, 11(1), 13-24. https://doi.org/10.1002/kpm.187

Van Den Hooff, B., \& Ridder, J. A. (2004). Knowledge sharing in context: The influence of organizational commitment, communication climate and CMC use on knowledge sharing. Journal of Knowledge Management, 8(6), 117-130. https://doi.org/10.1108/1367327041056767 5

Walsham, G. (2018). Knowledge management: System and Practices. European Management Journal, 19(6), 599-608.

http://www.sciencedirect.com/science/articl 
e/pii/S0263237301000858

Wang, L., Li, S., \& You, Z. (2020). The effects of knowledge transfer on innovation capability: A moderated mediation model of absorptive capability and network reliance. Journal of High Technology Management Research, 31(1), 100372.

https://doi.org/10.1016/j.hitech.2020.10037 2

Yeşil, S., Koska, A., \& Büyükbeşe, T. (2013). Knowledge Sharing process, innovation capability and innovation performance: an empirical study. Procedia - Social and Behavioral Sciences, 75, 217-225.

https://doi.org/10.1016/j.sbspro.2013.04.025

Zizlavsky, O. (2016). Innovation performance measurement: Research into Czech business practice. Economic Research-Ekonomska Istrazivanja, 29(1), 816-838.

https://doi.org/10.1080/1331677X.2016.123 5983 


\section{APPENDIX: THE QUESTIONS IN THE QUESTIONNAIRE}

\section{Knowledge Donating}

I learn something new, and I make sure that the employees at my MSME can learn it too.

I share the information with employees at my MSME.

I share knowledge about the technical skills involved in their operations with the employees at my MSME.

I learn something new, and I make sure that other Bakpia MSME owners can learn it too.*

I share the information with other Bakpia MSME owners.

I share knowledge of technical skills about their operations with other Bakpia MSME owners.

\section{Knowledge Collecting}

Employees at my MSME tell me what they know about something new, when I ask about it.*

Employees at my MSME tell me about the technical skills of their operations, when I ask them about it.

Other Bakpia MSME owners tell me what they know about something new, when I ask about it.

Other Bakpia MSME owners tell me about the technical skills of their operations, when I ask them about it.

\section{Innovation Capability}

My MSME often tries new ideas.*

My MSME is looking for new methods to do things, related to its operational/ production activities.

My MSME is creative in its operating methods.

My MSME is often the first to market new products and services.

Innovation in my MSME was considered to be too risky and was rejected.*

My MSME's introduction of new products (Bakpia) has increased over the past five years.

\section{Innovation Performance}

My MSME has a novelty or innovation level for new Bakpia products.

My MSME applies the latest technological innovations to create new Bakpia products.

My MSME is quicker than our competitors in developing new Bakpia products.

The number of new Bakpia products introduced by my MSME to the market is more than my competitors have introduced.

My MSME can introduce some new products to the market before my competitors.

The high technological competitiveness in my MSME's production process is higher than that of my competitors.

My MSME is quicker to adopt the latest technological innovations for the production process than my competitors.

My MSME has a higher level of novelty than my competitors in the technology used in the production process.

My MSME has a faster rate of change in its processes, techniques, and technology than my competitors. 
